\title{
An Evaluation of the Discovery Time Programme
}

\author{
Rebecca Fisher \\ Educational Psychologist, Ministry of Education, Special Education, Porirua \\ Brenda Martin \\ Resource Teacher: Learning \& Behaviour, Porirua East Cluster
}

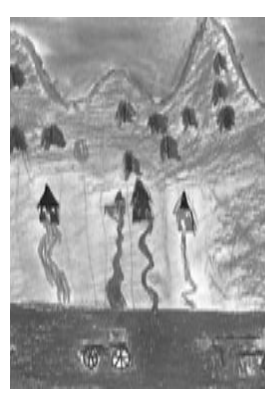

\begin{abstract}
This article describes the Discovery Time programme, a largely child-directed developmental programme, and discusses it in relation to the sociocultural approach to learning. It considers the effects of the programme on the development of children's oral language and cooperative social skills in a Year 1 classroom. Survey information gathered by the teacher indicated that the language and social skills of the children increased over a 10 week period. The review of the discovery time programme also considered information through interviews with key participants, observations of the programme in action and review of the child participants'stories and pictures. This additional information indicated that discovery time provided a positive learning environment and enjoyable experiences for the children, teacher and school community. The article concludes with suggestions for further developments of the programme within the school.
\end{abstract}

\section{Practice Paper \\ Keywords}

Learning activities, new entrants, oral language, play based curriculum, programme evaluation, social skills.

Play is the natural way in which children go about the business of learning. It enables them to integrate and consolidate a wealth of experiences that enhance their cognitive, physical, social and emotional development.

$$
\text { (Fisher, 2002, p. 128). }
$$

\section{WHAT IS DISCOVERY TIME?}

Discovery time is a sessional, action packed, activity based programme founded on the "developmental" or "choosing time" concept of the 1970's. Regularly scheduled, it provides opportunities for teachers to meet a wide range of student needs through well planned, structured, activity based experiences. Discovery time advocates for "play" as a legitimate learning activity for children at school.

A typical session would see the teacher planning and preparing a range of activities such as skipping, construction, puppetry, cooking, Lego, painting, craft activities, cooperative games or jigsaw puzzles. The teacher would begin by introducing the focus for the day that generally targets an essential skill (for example, sharing, including others, communicating, solving problems, persevering, and completing tasks). There might be a discussion about what this skill would look like and sound like, and how one would know if it was happening.
The activities for the day would be explained with many of these linking to the current curriculum work. The children then select and participate in activities. During the session the teacher takes the role of facilitator; observing, providing feedback, asking questions and encouraging the students. At the end of the session the class would come together to share what they had done and what they had learned.

The concept of Discovery Time began as a collaborative project between the resource teacher: learning and behaviour (RTLB) and junior syndicate teachers in a low decile, multicultural school. Teachers considered that the strong focus on literacy and numeracy in junior classes left little time for a more holistic approach to education and opportunities for children to learn through play. They believed that observed behaviour problems were occurring because students found it difficult to work independently, communicate effectively, take turns or share equipment and did not always have the physical skills to complete a task. They also identified that there were few opportunities for student directed learning or for 'hands on' experiential learning. They wanted to meet not only the cognitive but also the social, emotional and physical needs of students. Discovery Time was initiated to meet these identified needs.

The teachers developed their ideas about the programme from a theoretical base incorporating the following key elements from the literature:

- A sociocultural approach to learning

- Child directed, experiential learning opportunities

- Opportunities for peer collaboration in the learning process

- Teacher facilitation of learning that incorporates observation and reflection

- Teacher / student communication based on open-ended questions and reflective dialogue.

\section{THEORETICAL FOUNDATIONS FOR THE DISCOVERY TIME PROGRAMME}

\section{Sociocultural Approach to Learning}

Early theories of child development focused on individuals mastering linear stages of cognitive development, as in Piaget's stages of cognitive development (Shaffer, 1996). However, sociocultural theorists have placed far greater emphasis on the social context of children's learning where surrounding adults and peers have a shared role in the co-construction of learning (Cullen, 1998; Vygotsky, 1978). 
Our understanding of how children learn and develop has moved away from viewing this process as a journey of individual mastery to a journey that is a collective process. The child is viewed as an active participant in this process; shaping, and being shaped, by the shared culture in which they live (Greenfield, 2002; Nixon \& Aldwinckle, 2002). Māori perspectives on learning and development are similarly embedded in social interactions. Learning as a dynamic, socially interactive process is captured by the metaphor of a 'weaving staircase' or Poutama (Dyson, 1990; Royal-Tangaere, 1997). This view recognises the various experiences children bring to any given task and incorporate the collaboration of peers as well as adults in the learning process.

\section{Child-Directed Learning}

In New Zealand, recognition of the benefits of the sociocultural approach to learning can be seen in the early childhood curriculum, Te Whāriki (Ministry of Education, 1996). Discovery Time has been developed from sociocultural theories of learning and links learning outcomes with essential skills outlined in The New Zealand curriculum framework (Ministry of Education, 1993) and key competencies in the New Zealand curriculum draft for consultation (Ministry of Education, 2006). These documents highlight that interactions between adults and peers play an important role in cognitive development (Hipkins, 2005). Two of the Best Evidence syntheses (Alton-Lee, 2003; Farquhar, 2003), found that peer collaboration is central to the learning process and opportunities for child directed learning are related to positive educational outcomes for all students. However, despite the positive outcomes reported in the literature, opportunities to co-construct knowledge through play and social interactions with peers are substantially reduced when children begin school (Coolahan \& Mendez, 2000; Fisher, 2002). Fisher suggests that the curriculum should start from the child rather than expecting the child to start from the curriculum. This approach encourages children to become actively engaged in the learning process rather than being passive recipients of someone else's decision making and control, usually the teachers.

\section{Peer Collaboration}

Opportunities for social interactions are recommended as a core part of the curriculum rather than "extra-curricula" activities. Positive interactive play behaviour in young children is associated with active engagement in classroom learning activities. During interactive play it is also common for conflicts to arise among children as they learn to problem solve. They must consider differing points of view, new ideas and experience the possibilities of co-constructing shared understandings (Coolahan \& Mendez, 2000; Greenfield, 2002). There are long term benefits of social play for children's learning. For example, Marcon (2002) found significantly higher grades for students at the end of their sixth year at school when they had participated in child-initiated early learning experiences.

\section{Teacher Facilitated Learning}

While research clearly indicates the benefits of peer collaboration in the learning process, it also highlights the valuable role of the teacher in facilitating learning through a range of educational experiences (Alton-Lee, 2003).
Farquhar (2003) summarises quality teaching as practices which focus on children as learners and on their learning. Quality teaching facilitates children's dialogue, encourages cooperative as well as independent work and is concerned with the motivation and learning dispositions of young learners (Farquhar). A further recommendation is that teachers learn about children through observation and a sharing of common experiences that can be expressed through conversation and activities.

\section{Reflective Dialogue}

Taking time to talk with children and young people not only informs teachers about their current level of knowledge but it also has been demonstrated to be an effective strategy for learning. Allowing children and young people to use their own words to make sense of their experiences, their thoughts and ideas gives clear evidence on which to build the next stages of learning (Fisher, 2002). The use of open-ended questions as a way of scaffolding children's thinking is associated with better cognitive outcomes for students (Siraj-Blatchford, Sylva, Muttock, Gilden \& Bell, 2002). It enables teachers to enhance children's understanding of what they are doing, to express their ideas and to develop vocabulary through reflective dialogue and conversations (Williams, 1994). Encouraging reflective dialogue between peers and with teachers has been shown to promote meta-cognition (an awareness and control of their thinking processes) in young learners (Cullen, 1998; Cullen \& St George, 1996). Observations of children are also valuable ways of seeing what children know and can do in a range of both child-initiated and teacher-initiated activities (Drummond, 2003; Fisher, 2002).

The Discovery Time programme aims to incorporate the above key aspects of teaching and learning theory into practice. While the programme was developed from a theoretical base, the learning outcomes for students and teachers had not, until this point, been formally evaluated. This led to the collaborative evaluation project.

\section{PROGRAMME EVALUATION}

Evaluating education programmes within the context of current literature is one way to ensure that practice is informed by relevant theory. The aim of this evaluation was to document some of the predicted learning outcomes of the discovery time programme, facilitated in this instance for one 90-minute session per week, by applying principles of education research within the classroom context. The two essential skills chosen by the teacher in this setting were oral language and cooperative social skills. While the school had developed some means of measuring the effects of the programme on students learning, project staff considered that collaboration with an external evaluator could add value to the programme and provide direction for further development.

The programme was evaluated in a decile one, multicultural school, with predominantly Pasifika students. The evaluation focused on the Year 1 class (average age 5 years, 4 months). The teacher gathered survey information for each child, rating their oral language and cooperative social skills on a scale of 1-5 based on their observations at the start of the term and again 10 weeks later. 
Further information about the programme was collected through classroom observations, an interview with the teacher and recording of the "student voice" through pictures and stories.

\section{Survey Information}

The survey information indicated an increase in both target skills for all of the students as rated by the class teacher. Observable skills demonstrating social and cooperative competence included the ability to share, take turns, look after equipment and help to tidy up.

The rated social and cooperative skills increased on average for all students from 'sometimes demonstrating the skill' to 'mostly demonstrating the skill'.

Observable skills for oral language development included the ability to report back clearly, report back in sentences and the ability to reflect on what they did or achieved. Oral language skills also increased over the 10-week period from 'rarely demonstrating the skill' to 'sometimes demonstrating the skill'.

\section{Teacher Interview}

The interview data reflected a positive experience of discovery time since being implemented at the beginning of Term 3, 2005. It was described as, 'a time to stand back and see what they [students] can do. With the new students it's a good opportunity to pick up information about them.' Benefits for student learning were reported as turntaking skills, developing social language to enter games, some problem solving skills, learning to play games and oral language development. From a teaching perspective the benefits from the discovery time programme included, 'having time to sit down and interact with the children, to allow students to be the 'teacher', having time to spend with individuals'.

\section{Observations}

The students were observed taking turns, with and without adult support, during board games and with popular activities outside. They were observed engaging in cooperative play when tidying up together or building a shared construction like the train track. There were also examples of scaffolded learning between peers. This was observed when one child modelled or helped another child complete a task. The students demonstrated pride in their accomplishments during the discovery time session. They would frequently share their creations with each other and their teacher. The students were observed demonstrating emergent numeracy and literacy skills, counting and naming shapes as they played games, forming letters or words with play dough and writing their names on art work.

\section{Children's Information Sheets}

Information sheets filled in with the children reflected a range of skills and favourite activities during Discovery Time. Examples of how children talked about concepts like sharing included:

I tried to share with Tracey; I just gave her the moon hopper and she gave it back to me.
I shared with Jayden. Jayden gave the moon hopper to me.

I share things when I was playing with my friends, with the game.

\section{DISCUSSION}

The results indicated a positive increase in social skills for all students as rated by the class teacher, moving from 'sometimes' demonstrating these skills to 'mostly' demonstrating these skills. Observations of the students during discovery time supported the teacher rating of 'mostly' demonstrating the target social and cooperative skills. The students engaged in turntaking during board games and when playing with equipment outside. The class teacher and the teacher aide were observed modeling turntaking skills and prompted the students to tidy up after playing with an activity. The teacher also reported preparing her students to practice sharing and turntaking during discovery time. This appeared to help prompt the students when reporting back about what they had learned throughout the session.

The discovery time programme provided opportunities for not only social skill development but oral language development. Research has identified positive links between reflective dialogues with children and improved learning outcomes (Cullen, 1998; Fisher, 2002). The results also indicated a positive increase in oral language skills after 10 weeks of the discovery time programme, moving from 'sometimes able to report back clearly' to 'reporting back in sentences'. Observations of the reporting back supported these findings. Children were observed reporting the following statements:

\section{I learnt to draw, I drew Pinocchio.}

I liked the teddy bear game.

Be nice to people.

The teacher was observed interacting with the students, modeling social interactions like sharing and turntaking. She extended oral language through the use of open-ended questions, comments and positive reinforcement when these skills were demonstrated. The teacher also reported the benefits during this time to be able to step back and observe the students or interact with individuals or a small group. This was also supported by the observations. The involvement of the RTLB during the discovery time session appeared to work well. The RTLB was able to model different ways to promote problem solving with the children when conflict arose over sharing or compromising with construction ideas. She was also able to support the teachers in ways to encourage reporting back by involving herself in this process and prompting the students with questions.

The outcomes of the Discovery Time programme were hard to isolate through this type of evaluation due to the difficulty in controlling for other factors impacting on both social skill development and oral language development. With this evaluation design there was no way to accurately isolate the learning outcomes of the programme. 
A variety of other influences such as family expectations, maturation, modeling from peers, interactions with teachers or parents at other times of the day, could well have contributed to their skill development. A further area to evaluate could have been shifts in teaching and learning practices during the rest of the week that might be attributed to the teachers increased awareness of socio-cultural approaches to learning.

The perceived benefits from the teachers' and the students' obvious enjoyment of their Wednesday mornings, suggests the discovery time programme has added a valuable learning experience for teachers and students alike. The survey information suggests that both social skills and oral language skills can be developed through the programme.

\section{FUTURE DEVELOPMENTS}

Based on readings associated with the theory of the programme and the results of the evaluation, the teacher, RTLB and evaluator believed that discovery time could be further enhanced by making the following adjustments.

Increase the use of multicultural activities.

Sociocultural theories of learning acknowledge the importance of cultural experiences and contexts for learning (Podmore, Suavao \& Mapa, 2003: Royal-Tangaere, 1997). There is scope for incorporating more culturally relevant experiences and activities in the discovery time programme.

Incorporate parent/community support.

The discovery time programme advocates for community and parental involvement (Martin \& Hay, 2004). Once the programme has been well established within the school it would lend itself to strengthening the home school partnership by including parents in sessions.

Increase links to the curriculum.

One of the potential strengths of the programme is the flexibility to include activities that are closely related to current curriculum work within the class. The teacher involved was already working towards strengthening such links in the coming term.

\section{Utilise the information gathered for individualised programme adaptations.}

The survey information based on teacher observation could have uses beyond the tracking of skill development. It could also be a useful way of identifying and meeting the individual needs of all students.

In summary, the discovery time programme presented as a useful context for enhancing learning opportunities within the class and for meeting the diverse needs of students. In addition, this project illustrated the efficacy of different educational professionals engaging in collaborative, systemic planning and evaluation to support quality, theoretically supported education.

\section{REFERENCES}

Alton-Lee, A. (2003). Quality teaching for diverse students: Best evidence synthesis. Wellington, New Zealand: Ministry of Education.

Coolahan, K., \& Mendez, J. (2000). Preschool peer interactions and readiness to learn: Relationships between classroom peer play and learning behaviours and conduct. Journal of Educational Psychology, 92(3), 458-465.

Cullen, J. (1998). Influences on young children's knowledge: The case of road safety education. International Journal of Early Years Education, 6(1), 39-48.

Cullen, J., \& St George, A. (1996). Scripts for learning: Reflecting dynamics of classroom life. Journal for Australian Research in Early Childhood, 1, 10-19.

Drummond, M. (2003). Assessing children's learning ( $\left.2^{\text {nd }} e d\right)$. London: David Fulton.

Dyson, A. (1990). Weaving possibilities: Rethinking metaphors for early literacy development. The Reading Teacher, 44(3), 202-213.

Farquhar, S. (2003). Quality teaching early foundations: Best evidence synthesis. Wellington, New Zealand: Ministry of Education.

Fisher, J. (2002). Starting from the child: teaching and learning from 3 to 8 ( $2^{\text {nd }}$ ed.). Philadelphia: Open University Press.

Greenfield, C. (2002). The visibility and role of intersubjectivity and peer collaboration in young children's play and cognitive development. New Zealand Research in Early Childhood Education, 5, 49-65.

Hipkins, R. (2005). Thinking about the key competencies in the light of the intention to foster lifelong learning. Set, 3, 36-38.

Marcon, R. (2002). Moving up the grades: Relationship between preschool model and later school success. Early Childhood Research and Practice, 4(1), Retrieved May 20, 2006, from http://ecrp.uiuc.edu/v4n1/marcon. html.

Martin, B. \& Hay, G. (2004). "And now l'll cook the bacon". An exploration of teaching and learning through discovery time. CD-ROM. Porirua, New Zealand.

Ministry of Education (2006) The New Zealand curriculum: Draft for consultation 2006. Wellington, New Zealand: Learning Media.

Ministry of Education. (1996). Te Whāriki: He whāriki mātauranga mō ngā mokopuna o Aotearoa/Early childhood curriculum. Wellington, New Zealand: Learning Media.

Ministry of Education (1993). The New Zealand curriculum framework. Wellington: Author.

Nixon, D., \& Aldwinckle, M. (2002). Exploring child development from three to six years. Australia: Social Science Press.

Podmore, V; Sauvao, L. \& Mapa, L (2003). Socio-cultural perspectives on transition to school from pacific islands early childhood centres. International Journal of Early Years Education, 11(1), 33-42. 
Royal-Tangaere, A. (1997). Māori human development learning theory. In P. Whāiti, M. McCarthy, \& A. Durie (Eds.), Mai i Rangiātea: Māori wellbeing and development (pp. 46-59). Auckland, New Zealand: Auckland University Press.

Shaffer, D. (1996). Developmental Psychology: Childhood and Adolescence ( $4^{\text {th }}$ ed.). Pacific Grove, CA: Brooks/Cole Publishing.

Siraj-Blatchford, I., Sylva, K., Muttock, S., Gilden, R., \& Bell, D. (2002). Researching effective pedagogy in the early years study. Retrieved March 20, 2006, from http://www.dfes.gov.uk

Williams, G. (1994). Talk on the climbing frame

Early Childhood Development and Care, 102, 81-89.

Vygotsky, L. (1978). Mind in society: The developmental of higher psychological processes. Cambridge, MA: Harvard University Press.

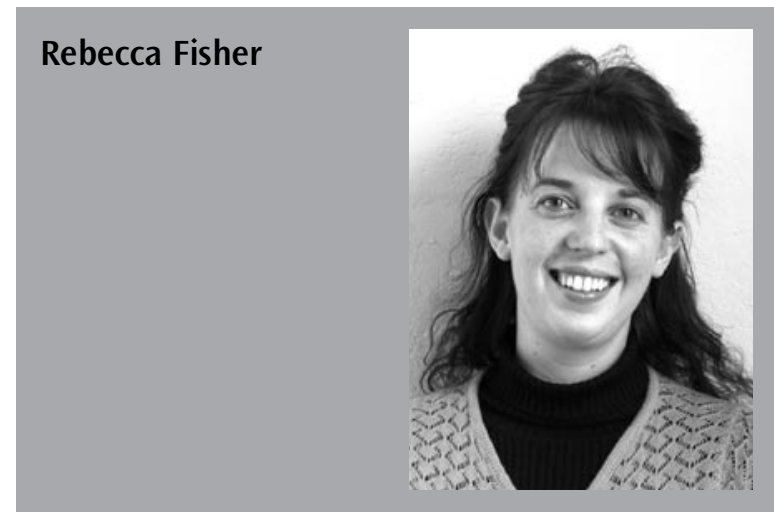

\section{AUTHOR PROFILE}

Rebecca Fisher is an Educational Psychologist working for Group Special Education. The Discovery Time project was a piece of work completed in 2005 as part of the Educational Psychology Internship. Rebecca has worked for Special Education for the past 2 years, currently as part of the Early Intervention Team.

\section{Author Contact}

Rebecca Fisher

Educational Psychologist

Ministry of Education, Special Education

PO Box 50136

Porirua

\section{Email}

rebecca.fisher@minedu.govt.nz

\section{Phone}

(04) 2380962

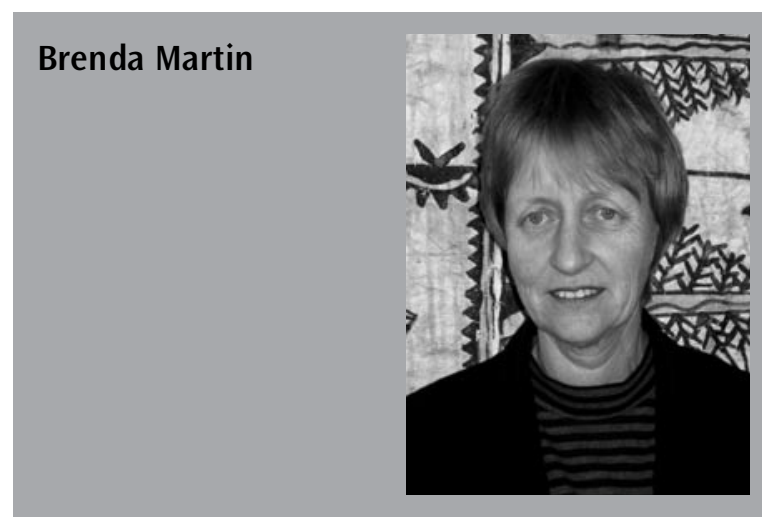

\section{AUTHOR PROFILE}

Brenda Martin (M.Ed., Dip ESSTN) is a Resource Teacher: Learning \& Behaviour in the Porirua East Cluster. The initial Discovery Time programme developed from her case work. It is now being run in over 30 classes in the Wellington area and interest is growing throughout New Zealand. Brenda has presented workshops on Discovery Time at the RTLB national conference (2005) and the NZ Reading Association national conference (2004). She continues to be involved in developing and extending the programme.

\section{Author Contact}

Brenda Martin

Resource Teacher: Learning \& Behaviour

Porirua East School

8 Martin Street

Porirua

\section{Email}

brendam@poriruaeast.school.nz

\section{Phone}

(04) 2370378 